while geology is represented by a geological hammer on some rocks in the foreground, and by a volcano in the distance.

The medal is to be awarded from time to time to persons who have made some notable contribution in connection with the zoology, botany, and geology of New Zealand; save in exceptional circumstances it is not to be awarded oftener than once in three years, and the recipient must have received the greater part of his education in New Zealand, or have resided in New Zealand for not less than ten years.

The remainder of the fund has been invested, and the interest on it may be used by the institute for making grants to persons who require assistance in connection with researches in New Zealand's natural history.

Communications with regard to the fund may be addressed to the secretary of the New Zealand Institute, Wellington, or to Dr. Chas. Chilton, Canterbury College, who acted as hon. treasurer until the fund was handed over to the institute.

\section{W. H. HUDLESTON, F.R.S.}

$\mathrm{W}^{\mathrm{E}}$ have to deplore the death, in his eighty-first year, of Wilfrid Hudleston Hudleston, one of the most distinguished of British geologists, whose combined knowledge of the main branches of the science, palæontological, stratigraphical, petrological and chemical, was unsurpassed.

Born at York, on June 2,1828 , he was the son of Dr. John Simpson, of Knaresborough (who married Elizabeth Ward, heiress of the Hudlestons of Cumberland), and he assumed the name of Hudleston, by letters patent, in 1867 .

After receiving education in schools at York and Uppingham, he entered St. John's College, Cambridge, and graduated B.A. in $185^{\circ}$. His attention was directed to geology during his last term at college, when he was present at a course of Sedgwick's lectures, but some years elapsed before his interest was concentrated on that subject. The study of law had engrossed much of his time, and he was called to the Bar in 1853 , but never practised.

Possessed of independent means, he spent the earlier years of manhood in travel in various parts of Europe and northern Africa. He was ever a keen sportsman, and the subject of ornithology attracted him, probably through his friendship with the late Alfred Newton, whom he accompanied on a visit to Lapland. Thus it was that he became one of the founders of the British Ornithologists' Union; and on December 9 of last year he attended a special meeting, held in the rooms of the Zoological Society, to celebrate the jubilee of the Union, when a gold medal was presented to him in honour of the occasion.

At the age of thirty-four, Mr. Hudleston decided to qualify himself for research work in natural science by courses of instruction which he undertook at Edinburgh, and afterwards at the Royal College of Chemistry in London. His ultimate career was determined in I866, when he was introduced to John Morris, professor of geology in University College, London. An absorbing interest in geology was aroused by that enthusiastic and gifted teacher, and Mr. Hudleston became a Fellow of the Geological Society in 1867 , and joined the Geologists' Association in $187 \mathrm{I}$. To the latter body he gave energetic service for a number of years, being chosen honorary secretary in 1874 , and president in 1881 ; and he conducted a number of notable excursions, his reports on which contain much original information.

The list of his geological publications commences in 1872 , and among the more impurtant are a series of papers on the Yorkshire Oolites, and others on the Gasteropoda of the Oolites, published in the Proceedings of the Geologists' Association and in the Geological Magazine.

In 1877 , in conjunction with the late J. F. Blake, he communicated to the Geological Society a memoir on "The Corallian Rocks of England," giving full particulars of these fossiliferous strata from Dorset to Yorkshire. It is sufficient to say that this paper is to be regarded as one of the geological classics.

In 1892 , with the cooperation of the late Edward Wilson, he published "A Catalogue of British Jurassic Gasteropoda," a work embodying all the critical knowledge of the writers. His chief work, one on which he was engaged for more than twenty years, was his " Monograph on the Gasteropoda of the Inferior Oolite," published by the Palæontographical Society ( $1887-1896)$.

Mr. Hudleston, who served for several years as secretary of the Geological Society, was elected president in 1892 ; and he was awarded the Wollaston medal in 1897 , soon after the completion of his great work on the Gasteropoda.

Apart from his detailed investigations, $\mathrm{Mr}$. Hudleston was the author of numerous essays, which afford abundant evidence of his shrewd criticism and sound judgment, with not a little dry humour. Among these articles may be mentioned those on the geology of Palestine, on the Tanganyika problem, on the eastern margin of the North Atlantic Basin, on Indian geology, and on the geological history of iron ores.

Mr. Hudleston was elected a Fellow of the Royal Society in 1884 . He was one of the founders of the Malacological Society, was president of Section C of the British Association at Bristol in 1898 , and was president at times of several provincial natural history societies. In later years, when he acquired a country residence at West Holme, near Wareham, in Dorset, he took an active part in the proceedings of the Dorset Natural History Field Club. He investigated in detail the structure of Creechbarrow Hill, near Wareham, and only last year published an important paper on some well-sections in connection with the local water-supply. He died at his Dorset home on January 29. A biography of him, to which we are indebted for many of the above particulars, appeared in the Geological Magazine for September, r904, accompanied by an excellent portrait and a list of publications.

H. B. W.

\section{NOTES}

Dr. Horace T. Brown, F.R.S., and Sir David Bruce, C.B., F.R.S., have been elected members of the Athenæum Club under the provisions of the rule which empowers the election of persons " of distinguished eminence in science, literature, the arts, or for public services."

We learn from the Pioneer Mail that Sir T. H. Holland, F.R.S., director of the Geological Survey of India, may be expected to arrive in England on leave during the coming summer preparatory to retirement, as he proposes to accept the offer of the chair of geology at Manchester University vacated by Prof. Boyd Dawkins, F.R.S.

THE honorary secretaries of the meeting of the British Association to be held in Winnipeg from August 25 to September I of this year are Mr. C. N. Bell, Mr. W. Sanford Evans (Mayor), Prof. M. A. Parker, and Prof. Swale Vincent. The office of the secretaries has been organised in the University of Manitoba, Winnipeg, Canada.

NO. 2050, VOL. 79] 